\title{
Parasitism of Diachasmimorpha longicaudata (Ashmead) on two fruit fly species
}

\author{
Parasitismo de Diachasmimorpha longicaudata (Ashmead) em duas \\ espécies de moscas-das-frutas
}

\author{
Laís Pacheco Sá', Clarice Diniz Alvarenga', Zenobia Cardoso dos Santos', Maria das Dores da \\ Cruz Souza ${ }^{1 *}$, Carlos Gustavo da Cruz', Maria Gisely Camargos' ${ }^{1}$, Teresinha Augusta Giustolin ${ }^{1}$
}

\begin{abstract}
The aim of the present study was to investigate the parasitism of two fruit fly species by different Diachasmimorpha longicaudata strains. Females of two parasitoid strains were reared on Ceratitis capitata or Anastrepha fraterculus that were conditioned in adapted containers. Individual parasitoids were offered 20 larvae for $1 \mathrm{~h}$, using no-choice (20 C. capitata or $20 \mathrm{~A}$. fraterculus) or free-choice (10 of each species) assays. Parasitism was verified by counting scars, and the pupae were classified as non-parasitized (no scars), parasitized (one scar), or superparasitized (multiple scars). Parasitism intensity was compared by evaluating the proportions of non-parasitized, parasitized, and superparasitized larvae. Parasitism intensity and scar frequency were analyzed as functions of host species and parasitoid strain, using chi-square tests. In the non-choice tests, females of both parasitoid strains parasitized the larvae, regardless of host species. However, when the parasitoids had a choice, they preferred to superparasitize $A$. fraterculus larvae, which are larger than $C$. capitata larvae. In addition, the female parasitoids parasitized most of the host larvae, regardless of parasitoid strain or host species. However, the frequency of non-parasitized pupae was higher when the offered host species was different from the one in which the parasitoid was reared, and the frequency of superparasitized pupae was higher when the offered host species was the same as the one in which the parasitoid was reared.
\end{abstract}

KEYWORDS: Superparasitism; host preference; parasitoid.
RESUMO: O objetivo deste trabalho foi avaliar o parasitismo de larvas de Tephritidae por duas linhagens de Diachasmimorpha longicaudata em duas espécies de mosca-das-frutas. Foram utilizadas fêmeas do parasitoide criadas sobre Ceratitis capitata ou Anastrepha fraterculus acondicionadas em gaiolas adaptadas. Para cada fêmea foram oferecidas 20 larvas durante 1 hora, em ensaio com chance de escolha (20 C. capitata ou 20 A. fraterculus) e sem chance de escolha (10 larvas de cada espécie). Após o parasitismo, o número de cicatrizes foi verificado e os pupários classificados como: não parasitados (ausência de cicatrizes), parasitados (presença de uma cicatriz) e superparasitados (duas ou mais cicatrizes). A intensidade de parasitismo foi avaliada por meio da proporção de larvas não parasitadas, parasitadas ou superparasitadas. As variáveis intensidade de parasitismo e frequência de cicatrizes em virtude do hospedeiro e da linhagem do parasitoide foram analisadas quanto à distribuição de frequência utilizando-se o teste qui-quadrado. No teste sem escolha, independentemente da espécie hospedeira, as fêmeas das duas linhagens parasitaram as larvas oferecidas e, quando tiveram escolha, preferiram superparasitar larvas de $A$. fraterculus, que são maiores que as de $C$. capitata. A frequência de pupários sem cicatriz foi maior quando o hospedeiro oferecido foi diferente daquele em que a fêmea foi criada. Independentemente da linhagem do parasitoide, as fêmeas parasitam a maioria das larvas hospedeiras das duas espécies, mas discriminam o hospedeiro, preferindo superparasitar a espécie na qual foi criada o hospedeiro. $A$. fraterculus foi o preferido para postura de fêmeas.

PALAVRAS-CHAVE: superparasitismo; preferência hospedeira; parasitoide. 


\section{INTRODUCTION}

Diachasmimorpha longicaudata (Ashmead) (Hymenoptera: Braconidae) is a larval-pupal endoparasitoid of fruit flies (Diptera: Tephritidae) in tropical and subtropical regions. The parasitoid can be reared on both Anastrepha spp. and Ceratitis capitata (Wiedemann), which can be advantageous when using the species to simultaneously control multiple tephritid species (OVRUSKI, 2003; VAN NIEUWENHOVE et al., 2012).

The measurable biological parameters of $D$. longicaudata parasitism have been evaluated previously in Anastrepha suspensa Loew (LAWRENCE et al., 1976), Anastrepha ludens Loew (MONTOYA et al., 2003), and C. capitata (OVRUSKI et al., 2003). However, few studies have investigated the development of $D$. longicaudata in different hosts or the parasitism behavior of $D$. longicaudata when offered different host species simultaneously. The few studies that have been conducted with these objectives have reported that $D$. longicaudata superparasitizes both $A$. fraterculus and $C$. capitata (ALTAFINI et al., 2013; MEIRELLES et al., 2013).

Host discrimination ability, i.e., the ability to recognize previously parasitized hosts, has been reported for several parasitoids and can result in subsequent rejection or superparasitization (VAN ALPHEN; VISSER, 1990). At one time, superparasitism was considered to result from parasitoid error, since there were no apparent benefits to laying eggs in previously parasitized hosts. However, it is now recognized that superparasitism can promote natural selection by fostering intraspecific competition (BAKKER et al., 1985). GONZÁLEZ et al. (2007) even suggested that superparasitism could have positive effects on $D$. longicaudata populations by promoting the selection of better flying ability and greater female production, thereby increasing populations' reproductive success. Indeed, even though female D. longicaudata exhibit host discrimination ability, the females prefer to superparasitize previously infected hosts, a behavior whose negative effects on offspring demography have yet to be reported (MONTOYA et al., 2003; MONTOYA et al., 2012).

Despite the acceptable performance of $D$. longicaudata in controlling fruit flies, few studies have evaluated the parasitism potential of the species' many strains. Because female parasitoids are expected to target the same host species in which they developed, understanding parasitoid-host interactions and parasitism behavior will facilitate the management of fruit fly populations in the field. Therefore, the aim of the present study was to evaluate the parasitism of two fruit fly species by two strains of $D$. longicaudata.

\section{MATERIALS AND METHODS}

Insects (fruit flies and parasitoids) were obtained from colonies maintained at the Biological Control Laboratory of the State
University of Montes Claros (Minas Gerais, Brazil) under controlled conditions $\left(26 \pm 2^{\circ} \mathrm{C}, 65 \pm 10 \% \mathrm{RH}\right.$, and $12 \mathrm{~h}$ photoperiod).

Third instar $A$. fraterculus and C. capita larvae were used to rear two parasitoid strains (AS and CS, respectively) for 10 generations prior to the trials, and eight-day-old females were used in the experiments for both strains. For the tests, the female parasitoids were kept in transparent $500-\mathrm{mL}$ plastic containers (11 cm diameter, $8 \mathrm{~cm}$ height). Circular openings were cut in the container lids and covered with voile (a fine-meshed fabric), in order to simultaneously allow air flow and confine the insects. The containers were also covered laterally with paperboard, so that the females could not see one another, which could have affected their behavior. Two female parasitoids were kept in each container and were fed an artificial diet of honey and water, following the methodology of CARVALHO et al. (1998).

To facilitate mating and oviposition by the females, two newly emerged pairs were individualized in the experimental containers for $5 \mathrm{~d}$. Third-instar host larvae (A. fraterculus and/or $C$. capitata) were then enclosed in a structure of voile (i.e., parasitism exposure unit, PEU) and offered daily to the parasitoids for $3 \mathrm{~d}$. The presence of the male as well as the process of experience with the PEUs were terminated on the day before the start of the assay.

Two assays were performed, with either no choice of host species or with a free choice of host species. In the no-choice assays, parasitoids (CS or AS) were offered either 20 C. capitata larvae or $20 \mathrm{~A}$. fraterculus larvae, whereas in the free-choice assays, parasitoids (CS or AS) were offered PEUs containing both host species (10 C. capitata larvae and $10 \mathrm{~A}$. fraterculus larvae).

For all the assays, the PEUs were removed after $1 \mathrm{~h}$, and the parasitoid-exposed larvae were transferred to containers containing moist vermiculite, where they could pupate. Oviposition scars on the pupae were counted under a stereomicroscope, and the pupae were classified as non-parasitized (no scars), parasitized (one scar), or superparasitized (multiple scars). In order to allow the emergence of flies and parasitoids, the pupae were then transferred to containers with moist vermiculite and covered with voile.

A completely randomized design was used for both experiments, with four treatments (two strains $\times$ two hosts) and 25 replicates per treatment. The frequency distributions of parasitism intensity (non-parasitized, parasitized, and superparasitized pupae frequency) and scar frequency were analyzed using $\chi^{2}$ tests in SAS (SAS INSTITUTE, 2003).

\section{RESULTS}

The distribution of parasitism intensity in the no-choice assays was significantly influenced by host species $\left(\chi^{2}=261.16, \mathrm{p}<0.001\right.$; Fig. 1). When CS females were used, the frequency of non-parasitized $A$. fraterculus larvae was greater than that of non-parasitized C. capitata larvae, whereas the frequency of parasitized (one scar) 
C. capitata larvae was greater than that of parasitized $A$. fraterculus ones. Furthermore, among the superparasitized larvae, a relatively greater proportion of $A$. fraterculus pupae had two to four scars, whereas a relatively greater proportion of $C$. capitata pupae had five or more scars, and both host species received the same maximum number of scars (Fig. 1). Meanwhile, when AS females were used, most of the $C$. capitata larvae were non-parasitized, compared to $<10 \%$ of the $A$. fraterculus larvae $\left(\chi^{2}=261.16\right.$, $\mathrm{p}<0.001)$, and most of the scarred C. capitata pupae had two scars, whereas most of the scarred $A$. fraterculus pupae had three or more scars. Furthermore, the $A$. fraterculus pupae had a higher maximum number of scars ( $\mathrm{n}=19$; Fig. 1$)$.

The distribution of parasitism intensity was also significantly influenced by host species in the free-choice assays $\left(\chi^{2}=159.92, \mathrm{p}<0.001 ;\right.$ Fig. 2$)$. The CS females preferred to parasitize $A$. fraterculus larvae, leaving most $C$. capitata larvae non-parasitized; only $7 \%$ of the $A$. fraterculus larvae were non-parasitized. In addition, $C$. capitata was over-represented among the parasitized (one scar) larvae, whereas $A$. fraterculus was over-represented among the superparasitized (three or more scars) larvae (Fig. 2).
Similarly, the AS females also preferred to parasitize $A$. fraterculus larvae, most of which were superparasitized (two or more scars), and left most $C$. capitata larvae non-parasitized, and C. capitata was again over-represented among the parasitized (one scar) larvae, whereas $A$. fraterculus was over-represented among the superparasitized larvae. Furthermore, the $A$. fraterculus pupae had a higher maximum number of scars ( $\mathrm{n}=18$; Fig. 2).

Finally, even though both host species were consistently parasitized, assay type (no-choice and free-choice) and parasitoid strain each affected the distribution of parasitism intensity (Table 1). For example, superparasitism was more frequent in the no-choice assays, regardless of host species or parasitoid strain $\left(\chi^{2}=170.34, \mathrm{p}<0.001\right)$. In the assays with CS females, $-19 \%$ of the $A$. fraterculus larvae were non-parasitized, whereas only $-10 \%$ of the $C$. capitata larvae were non-parasitized. In the assays with AS females, $79 \%$ of the $A$. fraterculus larvae were superparasitized, whereas $>34 \%$ of the $C$. capitata larvae were non-parasitized. In the free-choice assay, both parasitoid strains preferred to superparasitize $A$. fraterculus larvae and parasitize (one scar) C. capitata larvae $\left(\chi^{2}=59.12, \mathrm{p}<0.001\right.$; Table 1$)$.

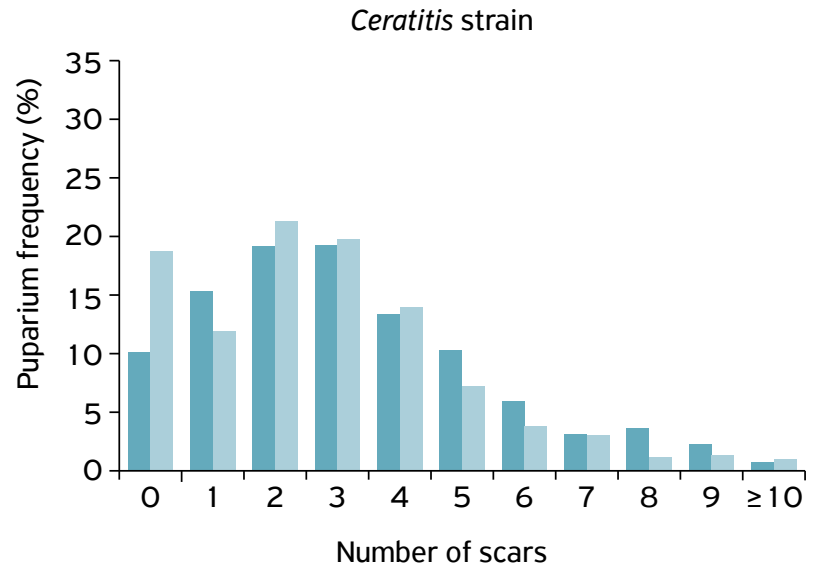

C. capitata $\mathrm{n}=459$
A. fraterculus $\mathrm{n}=466$

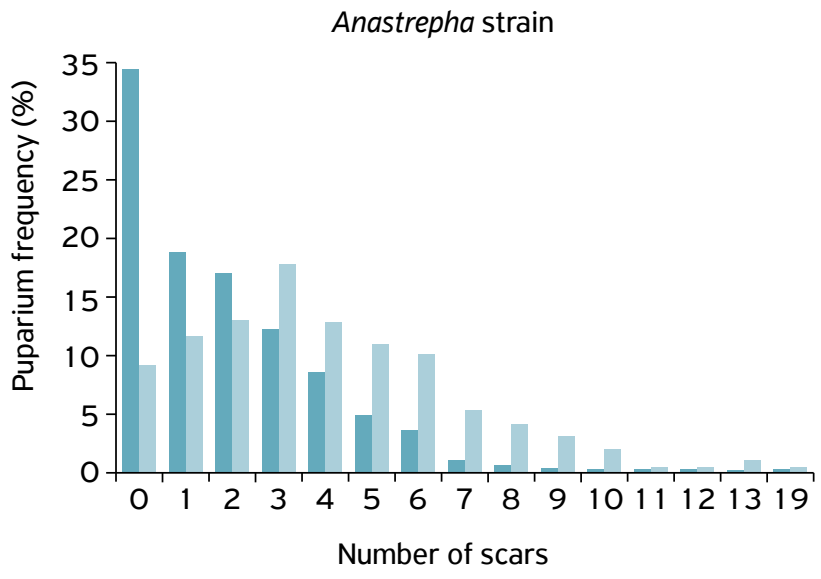

C. capitata $\mathrm{n}=475$

Figure 1. Distribution of parasitism intensity among the pupae of Anastrepha fraterculus and Ceratitis capitata parasitized by Diachasmimorpha longicaudata in no-choice assays. CS: Ceratitis strain; AS: Anastrepha strain.

Ceratitis strain

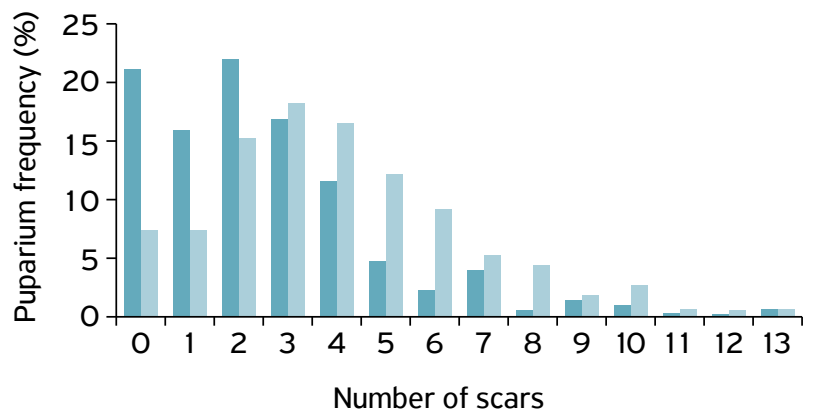

C. capitata $\mathrm{n}=235$

A. fraterculus $\mathrm{n}=233$

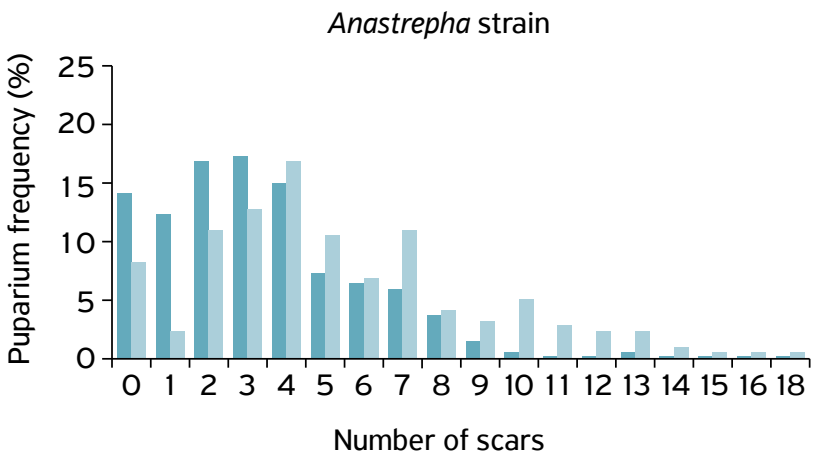

C. capitata $\mathrm{n}=475$

A. fraterculus $\mathrm{n}=443$

Figure 2. Distribution of parasitism intensity among the pupae of Anastrepha fraterculus and Ceratitis capitata parasitized by Diachasmimorpha longicaudata in free-choice assays. CS: Ceratitis strain; AS: Anastrepha strain. 


\section{DISCUSSION}

The distribution of parasitism intensity among the no-choice assays suggests that female parasitoids prefer not to parasitize unknown host species. For example, regardless of parasitoid strain, the frequency of non-parasitized pupae was higher when the offered host species was different from the one in which the parasitoid was reared (Fig. 1). However, C. capitata larvae were preferred by the females to laying a few eggs, up to two scars. Similarly, MEIRELLES et al. (2013) dissected parasitized larvae and observed $\leq 3$ parasitoid eggs within C. capitata larvae but $\leq 6$ parasitoid eggs within $A$. fraterculus larvae. In contrast, $\mathrm{CS}$ females preferred to superparasitize their original host. Meanwhile, among the free-choice assays (Fig. 2), A. fraterculus larvae were more intensely superparasitized than C. capitata ones. Our results resemble those of OVRUSKI et al. (2011), who also reported that $D$. longicaudata females parasitize both $A$. fraterculus and C. capitata. However, when female parasitoids had no choice, the parasitism was similar, and when given a choice, parasitoids preferred to parasitize A. fraterculus larvae. ALTAFINI et al. (2013) also reported this behavior and mentioned that, although $D$. longicaudata superparasitized both hosts, $A$. fraterculus larvae received a greater number of scars.

The results of the present study suggest that individual D. longicaudata females have preferred host species and that, when given a choice, select host larvae accordingly. SAMPAIO et al. (2001) reported that the parasitoid Aphidius colemani Viereck (Hymenoptera: Braconidae) preferred to parasitize Aphis gossypii Glover (Hemiptera: Aphididae), even though it was previously reared on Myzus persicae Sulzer (Hemiptera: Aphididae). In the present study, the distribution of parasitism intensity indicated that female $D$. longicaudata, in the absence of choice, were more likely to superparasitize their original hosts (Table 1). This suggests that host acceptance or preference by parasitoids can be influenced by larval environment. In the no-choice assays, $D$. longicaudata parasitized its original host, and in the free-choice assays, the parasitoid preferred to parasitize the larger host, $A$. fraterculus, as reported previously (MESSING et al., 1993; CANCINO et al., 2002; LOPEZ et al., 2009). This preference for larger hosts may indicate an adaptation for producing larger offspring and, consequently, more efficient in the search for hosts, since the size of the host can directly influence the size of the parasitoid (MEIRELLES et al., 2013) and this may interfere with the search efficiency of its host (LAWRENCE et al., 1976; GODFRAY, 1994). Larger individuals may exhibit greater fertility and fecundity (JERVIS, 2005).

According to the results of the present study, it is clear that female $D$. longicaudata parasitize most available host larvae, regardless of parasitoid strain or host species, but discriminate among hosts, in regard to superparasitism. Therefore, elucidating the effects that rearing $D$. longicaudata on different hosts will have on production efficiency, production cost, and efficiency of host suppression are important for deciding which host to use in the breeding of $D$. longicaudata for biological control programs.

\section{ACKNOWLEDGMENTS}

This work was supported by a grant from the Minas Gerais State Foundation for Research Support (no. APQ-01422-12), a $\mathrm{PhD}$ scholarship from the Coordination for the Improvement of Higher Level Personnel, and a grant from the Brazilian National Council for Scientific and Technological Development (no. PQ-309676/2015-0).

Table 1. Percent distribution of parasitism intensity among the pupae of Anastrepha fraterculus and Ceratitis capitata parasitized by Diachasmimorpha longicaudata.

\begin{tabular}{|c|c|c|c|c|}
\hline Host/Parasitoid (Assay type) & Non-parasitized (n) & Parasitized (n) & Superparasitized (n) & Total (n) \\
\hline $\mathrm{C} / \mathrm{CS}(\mathrm{NC})^{1}$ & $9.81(45)$ & $15.03(69)$ & $75.16(345)$ & 459 \\
\hline $\mathrm{A} / \mathrm{CS}(\mathrm{NC})$ & $18.45(86)$ & $11.59(54)$ & $69.96(326)$ & 466 \\
\hline C/AS (NC) & $34.31(163)$ & $18.74(89)$ & $46.95(223)$ & 475 \\
\hline A/AS (NC) & $9.03(40)$ & $11.51(51)$ & $79.46(352)$ & 443 \\
\hline Total (n) & 334 & 263 & 1,246 & 1,843 \\
\hline $\mathrm{C} / \mathrm{CS}(\mathrm{WC})^{1}$ & $20.85(49)$ & $15.74(37)$ & $63.40(149)$ & 235 \\
\hline $\mathrm{A} / \mathrm{CS}(\mathrm{WC})$ & $7.30(17)$ & $7.30(17)$ & $85.41(199)$ & 233 \\
\hline C/AS (WC) & $13.96(31)$ & $12.16(27)$ & $73.87(164)$ & 222 \\
\hline A/AS (WC) & $8.11(18)$ & $2.25(5)$ & 89.64 (199) & 222 \\
\hline Total (n) & 115 & 86 & 711 & 912 \\
\hline
\end{tabular}

A: Anastrepha fraterculus; C: Ceratitis capitata CS: Ceratitis capitata parasitoid strain; AS: Anastrepha fraterculus parasitoid strain; NC: no choice assay; WC: with choice assay; $\mathrm{n}$ : frequency.

'Distribution significantly different than expected by chance ( $p<0.01$, chi-square test). 
ALTAFINI, D.L.; REDAELLI, L.R.; JAHNKE, S.M. Superparasitism of Ceratitis capitata and Anastrepha fraterculus (Diptera: Tephritidae) by Diachasmimorpha longicaudata (Hymenoptera: Braconidae). Florida Entomologist, Gainesville, v.96, n.2, p.391-395, 2013.

BAKKER, K.J.J.M.; VAN ALPHEN, F.H.D.; VAN BATENBURG, N.; VAN DER HOEVEN, H.W.; NELL, W.T.F.H.; VAN STRIEN-VAN LIEMPT, T.C.J. TURLINGS. The function of host discrimination and superparasitism in parasitoids. Oecologia, Berlin, v.67, n.4, p.572-576, 1985.

CARVALHO, R.S.; NASCIMENTO, A.S.; MATRANGOLO, W.J.R. Metodologia de criação do parasitoide exótico Diachasmimorpha longicaudata (Hymenoptera: Braconidae), visando estudos em laboratório e em campo. Cruz das Almas: Embrapa-CNPMF, 1998. $16 \mathrm{p}$.

CANCINO, J.; VILLALOBOS, P.; DE LA TORRE, S. Changes in the rearing process to improve the quality of mass production of the fruit fly parasitoid Diachasmimorpha longicaudata (Ashmead) (Hymenoptera: Braconidae). In: LEPPLA, N.C.; BLOEM, K.A.; LUCK, R.F. (Ed.). Quality control for mass-reared arthropods. Gainesville: University of Florida, Institute of Food and Agricultural Sciences, 2002. p.74-82.

GODFRAY, H.C.J. Parasitoids behavioral and evolutionary ecology. New Jersey: Princeton University Press, 1994. 474p.

GONZÁLEZ, P.I.; MONTOYA, P.; PEREZ-LACHAUD, G.; CANCINO, J.; LIEDO, P. Superparasitism in mass reared Diachasmimorpha longicaudata (Ashmead) (Hymenoptera: Braconidae), a parasitoid of fruit flies (Diptera: Tephritidae). Biological Control, Orlando, v.40, n.3, p.320-326, 2007.

JERVIS, M.A. Insects as natural enemies: A practical perspective. Dordrecht: Springer, 2005. 755 p.

LAWRENCE, P.O.; BARANOWSKI, R.M.; GREANY, P.D. Effect of host age on development of Biosteres (=Opius) longicaudatus, a parasitoid of the Caribbean fruit fly, Anastrepha suspensa. Florida Entomologist, Gainesville, v.59, n.1, p.33-39, 1976.

LÓPEZ, O.P.; HÉNAUT, Y.; CANCINO, J.; LAMBIN, M.; CRUZ-LÓPEZ, L.; ROJAS, J.C. Is Host size an indicator of quality in the mass-reared parasitoid Diachasmimorpha longicaudata (Hymenoptera: Braconidae)? Florida Entomologist, Gainesville, v.92, n.3, p.441-449, 2009.

MEIRELLES, R.N.; REDAELLI, L.R.; OURIQUE, C.B. Comparative biology of Diachasmimorpha longicaudata (Hymenoptera: Braconidae) reared on Anastrepha fraterculus and Ceratitis capitata (Diptera: Tephritidae). Florida Entomologist, Gainesville, v.96, n.2, p.412-418, 2013.
MESSING, R.H.; KLUNGNESS, L.M.; PURCELL, M.; WONG, T.T.Y. Quality control parameters of mass-reared opine parasitoids used in augmentative biological control of Tephritid fruit flies in Hawaii. Biological Control, San Diego, v.3, p.140-147, 1993.

MONTOYA, P.; BENREY, B.; BARRERA, J.F.; ZENIL, M.; RUIZ, L.; LIEDO, P. Oviposition behavior and conspecific host discrimination in Diachasmimorpha longicaudata (Hymenoptera: Braconidae), a fruit fly parasitoid. Biocontrol Science and Technology, New York, v.13, n.7, p.683-690, 2003.

MONTOYA, P.; PÉREZ-LACHAUD, G.; LIEDO, P. Superparasitism in the fruit flyparasitoid Diachasmimorpha longicaudata (Hymenoptera: Braconidae) and the implications for mass rearing and augmentative release. Insects, Basel, v.3, p.900-911, 2012.

MONTOYA, P.; CANCINO, J.; PÉREZ-LACHAUD, G.; LIEDO, $P$. Host size, superparasitism and sex ratio in mass-reared Diachasmimorpha longicaudata, a fruit fly parasitoid. BioControl, Dordrecht, v.56, p.11-17, 2011.

OVRUSKI, S.M.; COLIN, C.; SORIA, A.; OROÑO, L.; SCHLISERMAN, P. Introducción y producción en laboratorio de Diachasmimorpha tryoniy Diachasmimorpha longicaudata (Hymenoptera: Braconidae) para el control biológico de Ceratitis capitata (Diptera: Tephritidae) en la Argentina. Revista de la Sociedad Entomológica Argentina, Buenos Aires, v.62, p.49-59, 2003.

OVRUSKI, S.M.; BEZDJIAN, L.P.; VAN NIEUWENHOVE, G.A.; ALBORNOZ-MEDINA, P.; SCHLISERMAN, P. Host preference by Diachasmimorpha longicaudata (Hymneoptera: Braconidae) reared on larvae of Anastrepha fraterculus and Ceratitis capitata (Diptera: Tephritidae). Florida Entomologist, Gainesville, v.94, p.195-200, 2011.

SAMPAIO, M.V.; BUENO, V.H.P.; VAN LENTEREN, J.C. Preferência de Aphidius colemani Viereck (Hymenoptera: Aphidiidae) por Myzus persicae (Sulzer) e Aphis gossypii Glover (Hemiptera: Aphididae). Neotropical Entomology, Londrina, v.30, n.4, p.655-660, 2001.

SAS INSTITUTE INC.SAS/STAT User's guide.Version 9.0. Cary, NC: SAS Institute Inc, 2003.

VAN NIEUWENHOVE, G. A.; BEZDJIAN, L. P.; OVRUSKI, S. M. Effect of exposure time and ratio of hosts to female parasitoids on offspring production of Diachasmimorpha longicaudata (Hymneoptera: Braconidae) reared on Anastrepha fraterculus (Diptera: Tephritidae) larvae. Florida Entomologist, Gainesville, v.95, n. 1, p.99-104, 2012.

VAN ALPHEN, J.J.M.; VISSER, M.E. Superparasitism as an adaptive strategy for insect parasitoids. Annual Review of Entomology, Stanford, v.35, p.59-79, 1990. 